\title{
Comparative Growth Analysis of Upland Rice and Maize Grown under Different Soil Moisture Conditions*
}

\author{
Akira Yamauchi, Yasuhiro Kono and Jiro TATSumi \\ (School of Agriculture, Nagoya University, Chikusa, \\ Nagoya 464, Japan) \\ Received December 20, 1986
}

\begin{abstract}
The growth of upland rice, a species with a relatively large waterlogging tolerance capacity, and maize, a species with a relatively large drought tolerance capacity, under waterlogged, moderate soil moisture and drought conditions were investigated from seeding to heading stage by means of growth analysis. Upland rice showed more vigorous growth in terms of dry matter production and RGR under waterlogged conditions than drought conditions, and a reverse trend was evident in maize. Analyzing RGR into its components, NAR with an additive effect of LAR principally determined RGR in upland rice, while NAR showed a clear correspondence with RGR in maize. Nitrogen (N) concentration in leaf blades of both species showed considerably close relationship with NAR and thus RGR. The difference of the ratios of $\mathrm{N}$ content in leaf blades of a plant to the number of roots, which were considered to express the root activity, also well corresponded with those in NAR and RGR for both species. Furthermore, intimate relationships between RGR of roots and NAR were also found. These facts indicate that the distinct growth responses which upland rice and maize showed under waterlogged and drought conditions well reflected the capacity of waterlogging and drought tolerances of each species ; and the responses largely depended on the activity and the growth of roots exhibited under those different soil moisture conditions.

Key words : Drought tolerance, Growth analysis, Oryza sativa L., Root, Root activity, Root growth, Waterlogging tolerance, Zea mays L.

異なる土埕水分条件下における陸稲とトウモロコシの比較生長解析：山内章・河野恭広・翼二郎（名古屋大 学農学部)

要 旨：イネ科作物の中で, 耐湿性程度の大きい陸稲(農林 11 号) と, 耐旱性程度の大きいトウモロコシ(ゴー ルデンクロスバンタム）を，湿潤（M区)，乾燥（D区)，湛水（W区）の土壌水分条件下で，幼植物期から 出穂期まで生育させ，その生長を生長解析によって比較，検討した。乾物量，RGRの推移によって，両種の 生長を比較すると, 陸稲は乾燥条件下よりも湛水条件下で比較的良い生育を示し，トウモロコシではその逆 の傾向を示した，陸畄の RGR の土㙵水分条件による差異は，NAR と LAR の両方に，トウモロコシでは 主にNAR の差異によく一致した。そこでNAR と関係の深い葉身中の窒素濃度を調べたところ，両種の NAR，そしてRGR との間に密接な関係が認められた。また，根の機能を反映していると考えられる，各個 体の葉身の窒素含量の根数に対する比とNAR を比較すると，それらは両種ともよく一致した。さらに根の RGR とNAR との間にも密接な関係が認められた。 以上の結果は，陸稲とトウモロコシが湛水・乾燥条件下 で示した特徵的な生長反応は，両種の耐湿性・耐旱性程度の違いをよく反映しており，そして，その生長反 応は，根の機能・生長に強く依存していることを示している。 キーワード：生長解析，耐旱性，耐湿性，トウモロコシ，根，根の機能，根の生長，陸稲。
\end{abstract}

The plants differ in the capacities to grow under different soil moisture conditions. We previously made a quantitative comparison on waterlogging and drought tolerances among 9 species of summer cereals ${ }^{7}$. The tolerances were evaluated on the basis of the dry matter production and water-use efficiency of the plants grown from seeding stage to maturity under different soil moisture conditions. We found that the cereals were divided into two groups; one group consisted of the cereals

* The outline of this paper was presented in the 181st meeting of the Crop Science Society of Japan, Utsunomiya, April 1986. which produced more dry matter under waterlogged conditions than drought conditions (crops with relatively large waterlogging tolerance capacities (RLWTC)) and the other group consisted of the cereals which produced more dry matter under drought conditions than waterlogged conditions (crops with relatively large drought tolerance capacities (RLDTC)).

Much is known about the morphological, physiological and biochemical responses of plants to drought ${ }^{13)}$ and waterlogged conditions ${ }^{6)}$; however, most of the studies are on their responses for relatively short term, 
which is often no greater than one day. Passioura ${ }^{13)}$ pointed out that the drought tolerance is an appropriate term to an ontogenetic time scale and thus the connection of short-term response of a plant to drought conditions to drought tolerance of the plant is obscure.

Besides, characteristics of a plant involved in the waterlogging tolerance such as the ability to develop aerenchyma in stems and roots $^{1)}$, the ability to produce new adventitious roots, the ability to tolerate the toxic substances produced in waterlogged soil ${ }^{6,11)}$ are rather long-term responses. Consequently, the short-term responses of plants to waterlogged and drought conditions can not be directly related to their capacities to grow under these soil moisture conditions.

In the present study, we picked out upland rice as a crop with a RLWTC and maize as a crop with a RLDTC among the cereals studied previously ${ }^{7}$. Their growth under moderate soil moisture, drought and waterlogged conditions were investigated and compared from their 4th-leaf stages to heading by means of growth analysis. We paid much attention to the responses occurred in roots, which is often neglected in growth analysis.

\section{Materials and Methods}

A pregerminated seed of Upland rice (Oryza sativa L. cv., Norin 11) and maize (Zea mays L., cv. Golden Cross Bantam) was sown in a vinyl pot on July 5, 1984. The seedings were grown in a glasshouse. At their 4th-leaf stages, each of the seedings which showed the uniform growth was transplanted to a Wagner pot $(1 / 5000 \mathrm{a})$ containing $3.6 \mathrm{Kg}$ of air-dried Kisogawa loam soil (maximum water holding capacity ; $64.5 \%$ ). Two $\mathrm{g}$ of the synthetic compound fertilizer ( $\mathrm{N}, 14 \% ; \mathrm{P}_{2} \mathrm{O}_{5}, 16 \%$; $\mathrm{K}_{2} \mathrm{O}, 14 \%$ ) per pot was applied twice before sowing and on August 13.

Determination of dry weights was made on five plants of each species prior to the start of the treatments. The following treatments were started at 2 days after the transplanting (July $17)$ :(1) moderate soil moisture conditions ( $\mathrm{M}$ -plot); the weight of a pot was set to be $5.6 \mathrm{~kg}$ by adding water. (2) drought conditions (D -plot); the weight of a pot was maintained at $4.4 \mathrm{Kg}$ up to August 1 and thereafter the pot weight was increased to $4.6 \mathrm{Kg}$ by adding water to prevent the plants from wilting. (3) waterlogged conditions (W-plot); waterlogged conditions were maintained in the pots (the surface of water was a few centimeters above the soil surface). Soil moisture content in the $\mathrm{M}$-plot was calculated to be $45 \%$, and that in the D-plot was $12 \%$ before August 1 and 19\% after that, based on the maximum water holding capacity. To keep the soil moisture conditions close to the original conditions, the same amount of water with the reduced weight of the pot during a day was added to each pot once a day during the experimental period.

Three to five plants of upland rice were sampled on July 30, August 14 and at heading (the W-plot, September 17 ; the M-plot, October 3 ; the D-plot, October 18). Sampling of maize were done on July 30, August 9 and August 27. At the last sampling, the plants in the $\mathrm{M}$ - and the $\mathrm{D}$-plots were at the start of their silking stages, while the plants in the $\mathrm{W}$-plot had only their tassels.

On each sampling, measurements were carried out on the number of nodal roots, leaf area, and dry weights of shoots and roots separately. Shoots were dried at $80^{\circ} \mathrm{C}$ for $72 \mathrm{~h}$ and weighed. Root dry weight was determined by the method reported previously ${ }^{7}$. The dried leaf blades were ground by a vibrating mill and their nitrogen contents were determined by Kjeldahl method.

In both species, the time between the start of the treatments and the first sampling was termed the first period, the time between the first and the second sampling was termed the second period, and the time between the second and the last sampling was termed the third period.

\section{Results}

1. Growth responses in plant dry weight and leaf area Fig. 1 shows the changes in the dry weight of a whole plant, shoot and roots of upland rice and maize through time.

In upland rice, a whole plant dry weight in the D-plot was less than a half of that in the $\mathrm{M}$-plot, while in the $\mathrm{W}$-plot it was 1.5 times that in the $\mathbf{M}$-plot at the first sampling. During the second period, this order changed. The dry weight of a plant in the M-plot overstepped that in the $\mathrm{W}$-plot. As a result, the plant dry weight was greatest in the $M$ 

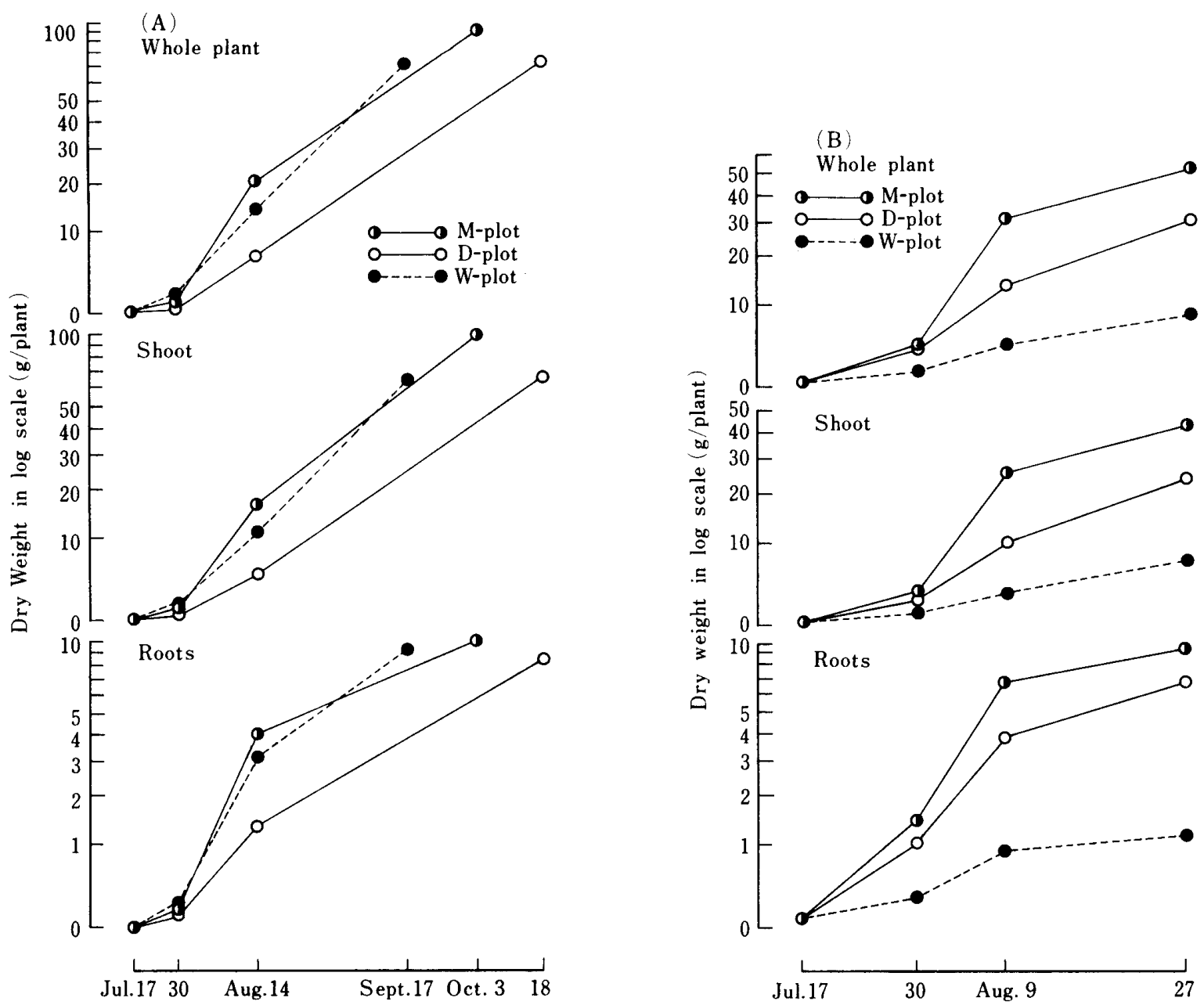

Fig. 1. Changes in dry weight of a whole plant, shoot and roots of upland rice (A) and maize (B) grown under different soil moisture conditions.

-plot, followed by the $\mathrm{W}$ - and the $\mathrm{D}$-plots at the second and the last sampling (heading).

In maize, a whole plant dry weight in the $M$ -plot was greater than in the D-plot, while a plant dry weight in the $\mathrm{W}$-plot was much smaller throughout the experimental period.

In both species, changes in the shoot dry weight and the whole plant dry weight showed nearly identical pattern. Root growth also showed the similar pattern except for that in the D-plot for both species. Root dry weight in the $\mathrm{D}$-plot was close to that in the $\mathrm{M}$-plot for upland rice, whereas for maize, the root dry weight in the $\mathrm{D}$-plot was greatest among three plots at the first sampling.

Patterns of changes in leaf area shown in Fig. 2 were similar to those of the plant dry weight for each species.

2. The shoot/root ratio Changes in the shoot/root ratio are shown in Fig. 3. In upland rice, over the first and the second periods, the shoot/root ratio in the $\mathrm{M}$ - and the D-plot went down. In the D-plot, the shoot/root ratio went down to its lowest value around 3.8 at the first sampling and maintained almost the same level up to the second sampling. After the second sampling, the shoot/root ratios of all plots increased.

In contrast, the shoot/root ratio of maize increased gradually from the start of treatments until the last sampling, except in the D -plot. The shoot/root ratio in the D-plot decreased up to the first sampling and thereafter shifted to increase.

3. RGR and its components Fig. 4 shows the changes in relative growth rate (RGR) of shoots and roots for upland rice and maize.

In upland rice, RGR decreased with the growth. However, the patterns of decrease were different among the three plots. In the $\mathrm{M}$ -plot, RGRs decreased linearly in both roots and shoot. In the D-plot, RGR of roots maintained almost the same level with that in the M-plot, while RGR of shoot was about 
$27 \%$ lower than that in the M-plot during the first period. From the second period, RGR of roots decreased more rapidly than that of shoots up to the heading. In the W-plot, RGRs of shoot and roots was about 11\% higher than that in the $\mathrm{M}$-plot, respectively, during the first period. However, subsequent
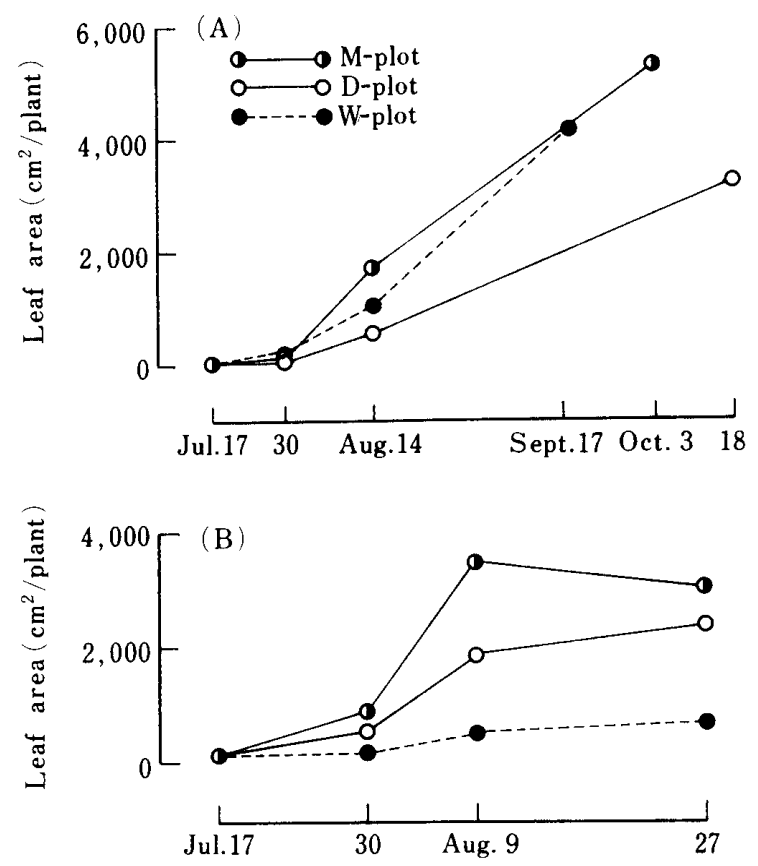

Fig. 2. Changes in leaf area of upland rice (A) and maize (B) grown under different soil moisture conditions.

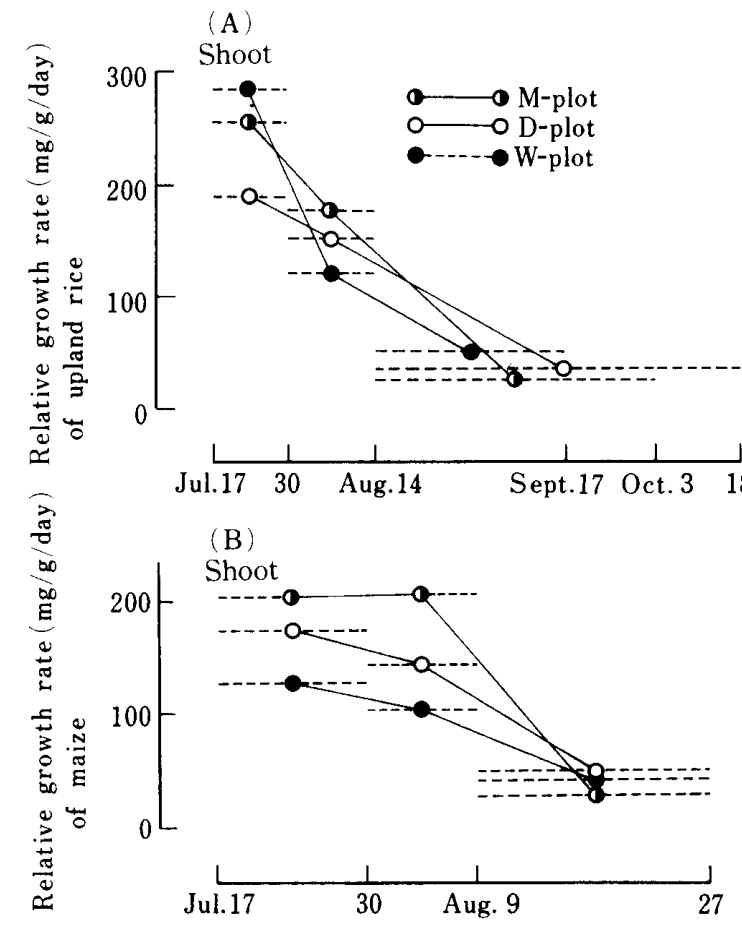

Fig. 4. Changes in relative growth rate (RGR) of upland rice (A) and maize (B) grown under different soil moisture conditions.
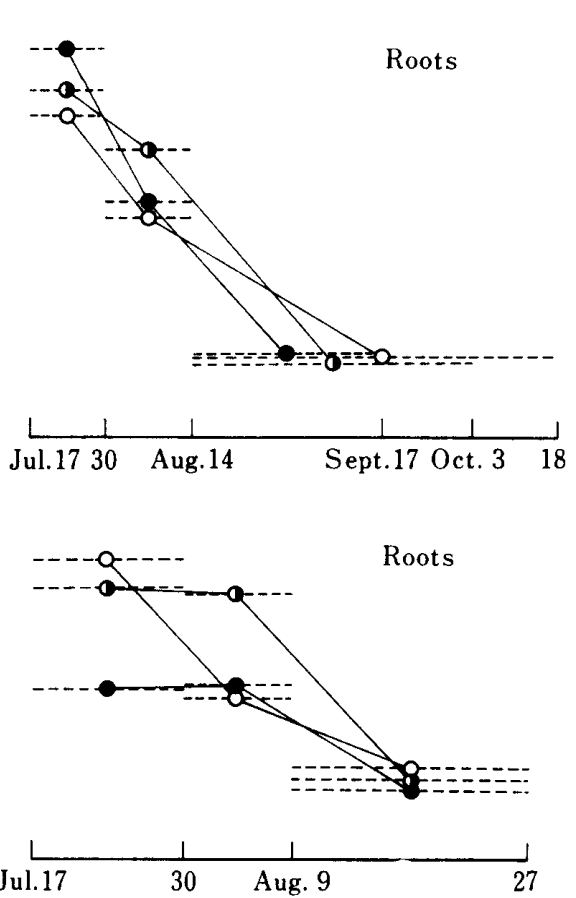

decrease of RGR in the W-plot in later periods was more rapid than in the other two plots.

In maize, RGRs of both shoot and roots
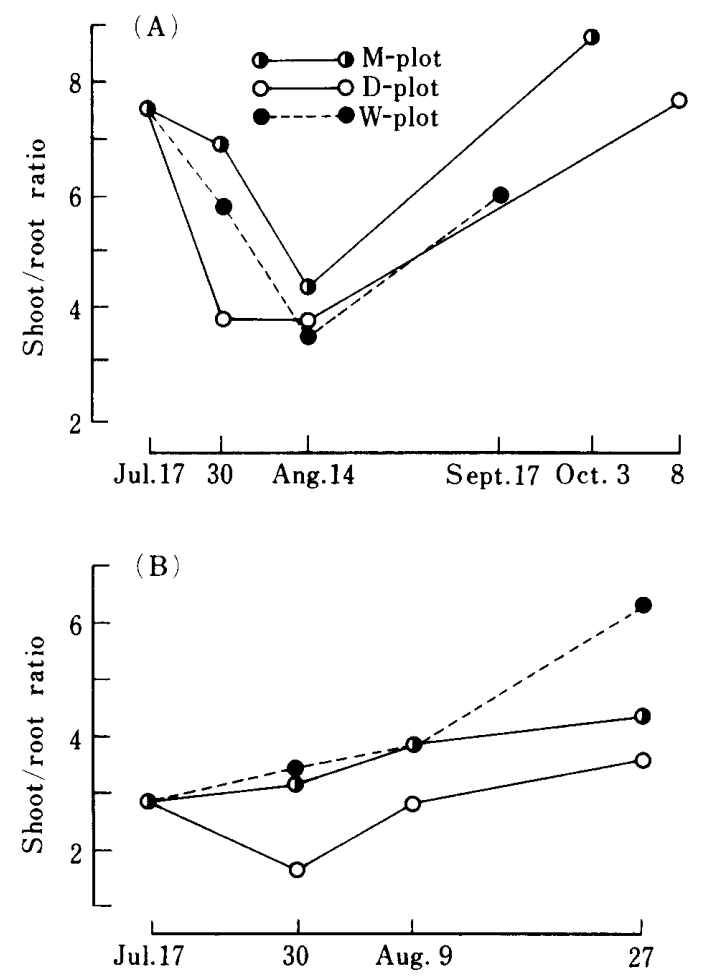

Fig. 3. Changes in the shoot/root ratio of upland rice (A) and maize (B) grown under different soil moisture conditions. 
were maintained at around $200 \mathrm{mg} / \mathrm{g} /$ day until the second period and decreased rapidly towards the heading in the $\mathrm{M}$-plot. In the $\mathrm{D}$ -plot, RGRs of both shoot and roots during the first period were close to those in the $\mathrm{M}$ -plot. Particularly RGR of roots was $217 \mathrm{mg} /$ $\mathrm{g} /$ day, which was highest among all. Thereafter, they decreased rapidly. Finally they converged around 20 to $50 \mathrm{mg} / \mathrm{g} /$ day. In the $\mathrm{W}$-plot, the pattern of decrease of RGR was similar to that in the $\mathrm{M}$-plot, but the values were almost half of that in the M-plot during the first and the second periods.

To compare the growth responses of the two species under different soil moisture conditions, RGR (a whole plant basis) was analyzed into net assimilation rate (NAR) and leaf area ratio (LAR). LAR was further analyzed into specific leaf area (SLA) and leaf weight ratio (LWR), and shown in Fig. 5. The discussion on the data here will be focused mainly on those during the first and the second periods since the rate of increase in the dry matter production declined during the third period especially in maize (Fig. 1).

Upland rice showed the highest NAR in the $\mathrm{W}$-plot during the first period when RGR was also highest among the three plots. However, during the second period, NAR in the $\mathrm{W}$-plot decreased and so did RGR, and became lowest among the three plots. In contrast, in the D-plot, NAR was lower than in the M -plot during both the first and the second periods. LARs in both the $\mathrm{D}$ - and the $\mathrm{W}$-plots were lower than those in the $\mathrm{M}$-plot throughout experimental period. Though, during the first period, LAR in the $\mathrm{W}$-plot was slightly higher than that in the D-plot, no marked difference was found during later periods between the two plots.

For upland rice, the differences in RGRs among the three plots were principally due to those in NARs with an additive effect of LARs. An exceptional case was found during the first period, when RGR as well as NAR were highest in the $\mathrm{W}$-plot, LAR in the $\mathrm{W}$ -plot was lower than that in the M-plot.

It is noteworthy that SLA was lowest in the $\mathrm{D}$-plot and highest in the $\mathrm{W}$-plot among the three plots throughout experiment, except for the first period. It means that the less water soil contained, the lower SLAs of the plants were. LWR showed a similar pattern to that of
LAR. So, low LAR in the D-plot can be attributed to low values of SLA and LWR, while low LAR in the $\mathrm{W}$-plot only to considerably low LWR.

On the other hand, maize showed the highest NAR in the D-plot during the first period, when RGR in the D-plot was very close to that in the $\mathrm{M}$-plot. In contrast, NAR in the $\mathrm{W}$ - plot was lowest during the first period and this low NAR was associated with low RGR. During the second period, a slight decrease of NAR in the D-plot and a slight increase in the $\mathrm{W}$-plot made the difference between the two smaller. NAR in the M-plot showed marked increase during the second period and became highest among the three plots, and so did their RGR accordingly.

LARs in the D- and the $\mathrm{W}$-plots were lower as compared with those in the M-plot during the first period, but no difference was found among the three plots during the second period. Therefore, LAR of maize did not show a clear correspondence with RGR.

For maize, the differences in RGR among the three plots were mainly attributed to those in NAR during the first and the second periods

SLA showed no distinct trend among the three plots unlike upland rice, while LWR showed rather lower values in the $\mathrm{D}$ - and the $\mathrm{W}$-plots as compared with those in the $\mathrm{M}$ -plot during the first and the second periods. LAR of maize was determined by additional effects of SLA and LWR.

\section{Discussion}

Distinct differences in the growth responses to waterlogged and drought conditions were observed between the two species. Salient features of the growth responses of each species are summarized as follows.

Upland rice grew more vigorously under waterlogged conditions (W-plot) than under drought conditions (D-plot) in terms of dry matter production (Fig. 1). The growth under waterlogged conditions was comparable even with that under moderate soil moisture conditions ( $\mathbf{M}$-plot) throughout experimental period. This vigorous growth was remarkable especially within two weeks from the start of treatment (the first period). During this period, the dry weights (Fig. 1) and RGRs (Fig. 4) of both shoot and roots in the $\mathrm{W}$-plot 
(A)
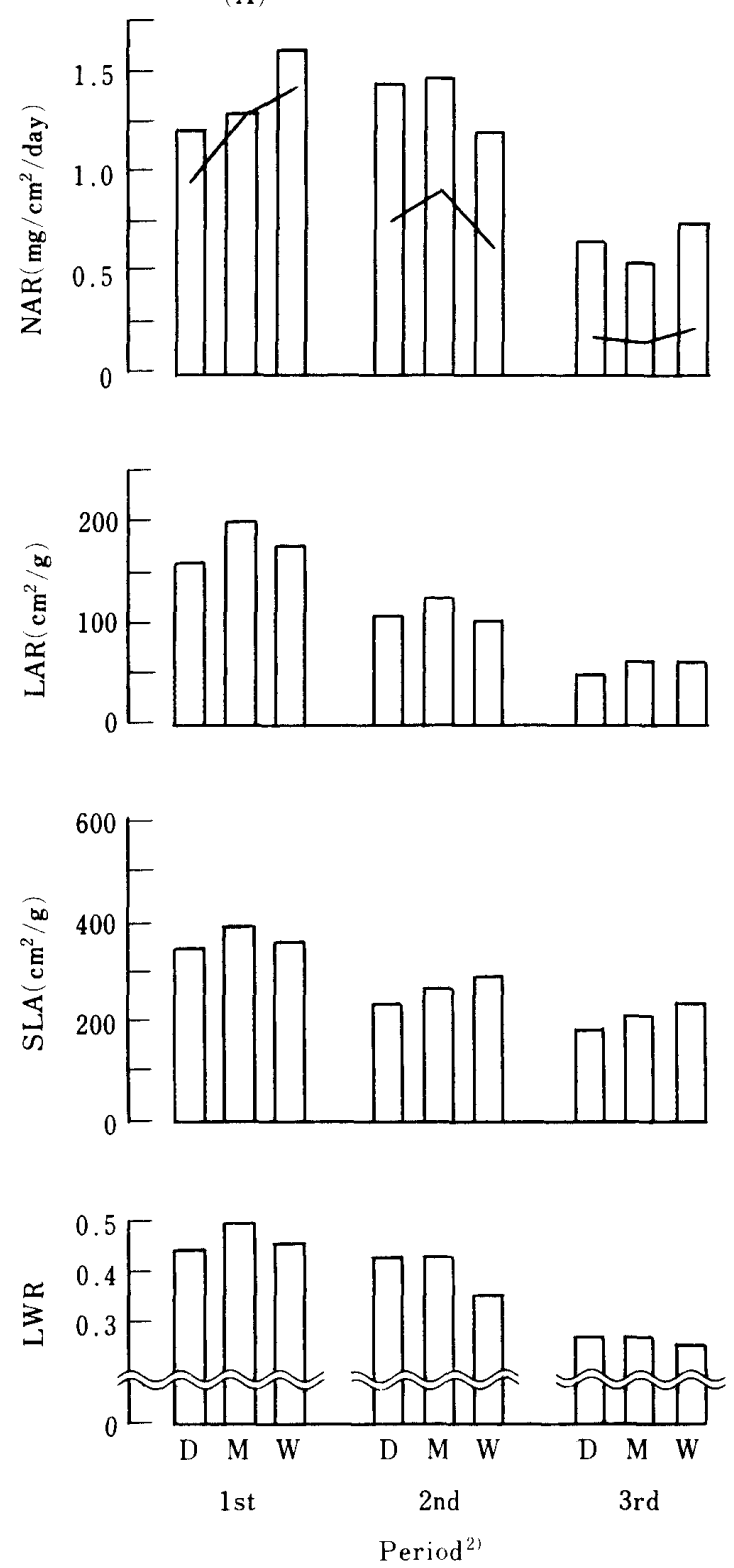

(B)
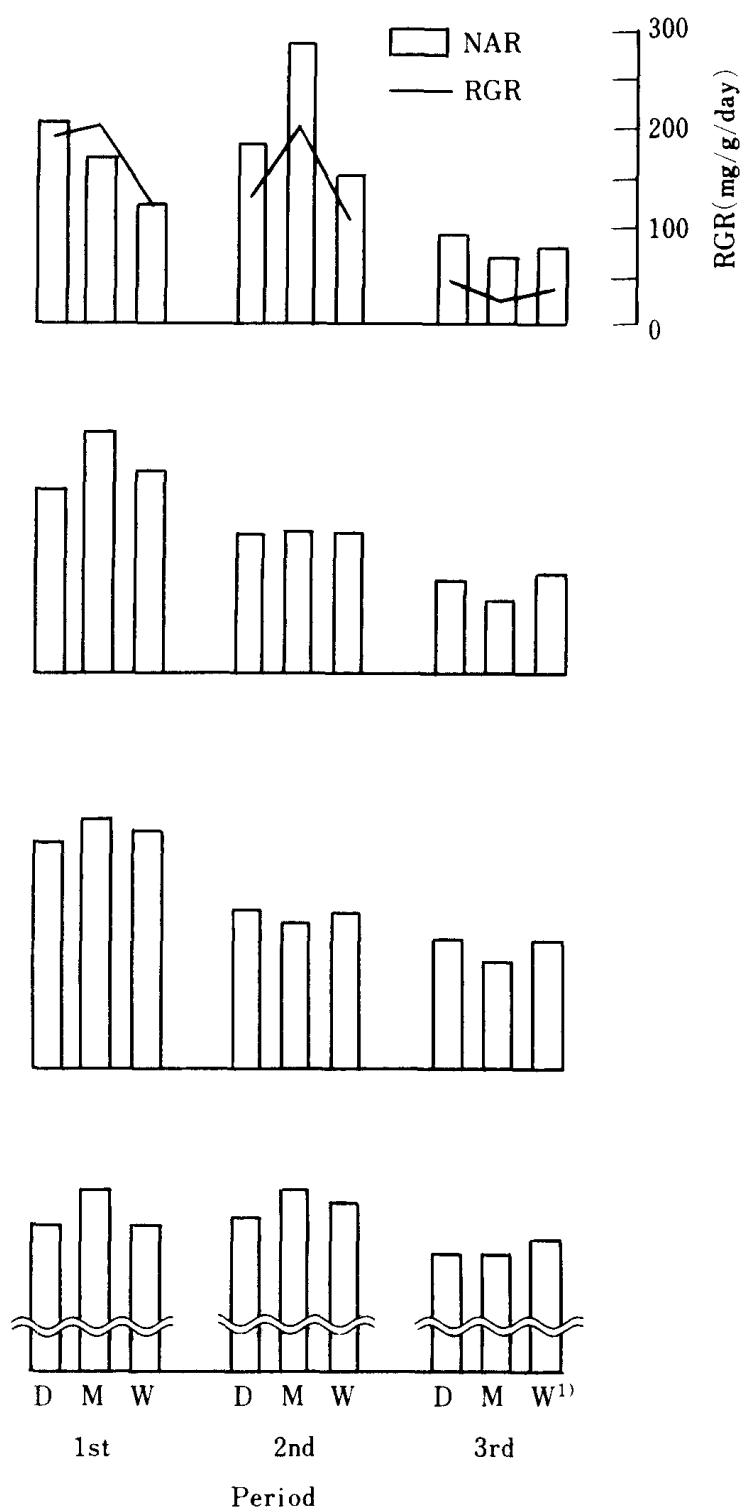

Fig. 5. Comparison between the differences in relative growth rate (RGR), and the differences in net assimilation rate (NAR), leaf area ratio (LAR), specific leaf area (SLA) and leaf weight ratio (LWR) of upland rice (A) and maize (B) grown under different soil moisture conditions. Note 1) D, D-plot; M, M-plot ; W, W-plot.

2) Upland rice : 1st, July 17-30 ; 2nd, July 30-Aug. 14;3rd, Aug. 14-Oct. 18 (D -plot), Aug. 14-Oct. 3 (M-plot), Aug. 14-Sept. 17 (W-plot). Maize : 1st, July 17 -30 ; 2nd, July 30-Aug. 8 ; 3rd, Aug. 8-27.

were greater than those in the $\mathrm{M}$-plot.

An interesting growth response to drought conditions was found in upland rice. It was that the leaf blades were thickened under drought conditions expressed by lowered SLA. This is considered to be a sort of xeromorphim, which has been observed in some plant species $^{4,18)}$.

In contrast, the growth of maize was more vigorous under drought conditions (D-plot) than under waterlogged conditions (W-plot). However, the growth in the $\mathrm{D}$-plot was comparable with that in the M-plot only during the first period, but it was relatively suppressed during later periods (Figs. 1 and 4 ). In the $\mathrm{W}$-plot, the growth of maize was severely suppressed, almost half of that in the M-plot in terms of RGR (Fig. 4). In addition, the effect of waterlogged conditions was more serious on root than shoot growth especially 
near heading (tasseling) stage, as shown in the shoot/root ratio (Fig. 3).

On the other hand, a growth response which was common to the two species was found. That was the promotion of the root growth as compared with shoot growth in the D-plot especially during the first period, as exhibited in the shoot/root ratio (Fig. 3). This response to drought conditions has been widely observed in many plant species ${ }^{13)}$. Not only relatively vigorous growth of the root system as compared with shoot were promoted, but also the absolute size of the root system became larger in some cases under relatively dry conditions ${ }^{3)}$. In this experiment, maize showed this response at the first sampling; the dry weight (Fig. 1) and RGR (Fig. 4) of roots of maize in the $\mathrm{D}$-plot were greater than those in the M-plot.

Previously ${ }^{7}$, upland rice was designated as a crop with RLWTC, while maize as a crop with RLDTC based on the dry matter production at their mature stages. Present results showed that this trend was found not only at maturity but at any time from seedling (4-th leaf stage) to heading (Fig. 1).

Besides, we made a growth analysis on these two crops in the present study. As a result, RGR of upland rice grown under waterlogged conditions was found to be higher than that grown under drought conditions, while RGR of maize was found to be higher when grown under drought conditions than that grown under waterlogged conditions, from seeding to heading stage (Fig. 4). Moreover, this trend was especially remarkable within two weeks after the plants was exposed to each soil moisture condition. An exceptional case was found in upland rice during the second period, whose possible cause will be discussed later.

Two main factors were involved in the growth responses of the two species to different soil moisture conditions (Fig. 5). One factor was the size of photosynthetic organ expressed by leaf area and LAR, and the other factor was the photosynthetic activity expressed by NAR.

Hsiao $^{2)}$ pointed out that the expansion of leaves is very sensitive to water stress in general. In our study, the expansion of leaves was depressed under drought conditions in upland rice and maize. In maize, leaf area was depressed more under waterlogged conditions
(Fig. 2). As shown in Fig. 5, LARs were lower in both the $\mathrm{D}$ - and the $\mathrm{W}$-plots than in the $\mathrm{M}$-plot for upland rice throughout all the periods and for maize during the first period. The lower LAR indicates that inhibitive effects were more serious on leaf expansion than the growth of other plant parts. However, the difference of LAR between the D- and the W - plots was not always in good agreement with that of RGR between the corresponding plots as pointed earlier.

A good correspondence with the trend of RGR was found in NAR as shown in Fig. 5. Similar to RGR, NAR of upland rice grown under waterlogged conditions was higher than that grown under drought conditions, while NAR of maize grown under drought conditions was higher than that grown under waterlogged conditions throughout the experimental period except for upland rice during the first period.

Therefore, the present study revealed that the RLWTC of upland rice was attributed to higher LAR during younger stage and higher NAR from seeding to heading stages under waterlogged conditions than drought conditions. The RLDTC of maize was attributed to the maintenance of higher NAR from seeding to heading stages under drought conditions than waterlogged conditions. Consequently, the growth responses of each species exhibited in the present experiment well reflected RLWTG and RLDTC previously found ${ }^{7)}$ in upland rice and maize, respectively.

Takeda et al. ${ }^{17)}$ made a growth analysis on some grasses grown under different soil moisture conditions during the seeding stages, which almost correspond to our first period. They obtained results similar to ours for upland rice and maize, except that NAR of maize was scarcely affected by waterlogged as well as drought conditions. In contrast, Tazaki et al. ${ }^{18)}$ attributed the decline of RGR in maize by drought treatment to that of NAR as well as LAR.

Wenkert et al. ${ }^{19)}$ attributed the inhibition of leaf expansion in maize grown under waterlogged conditions to the deficiencies in nitrogen and other major nutrients. Comparing the differences of LAR between the D- and the W -plots during the first and the second periods with that of $\mathrm{N}$ concentration in leaf blade (Fig. 6), they agreed well in upland rice for 

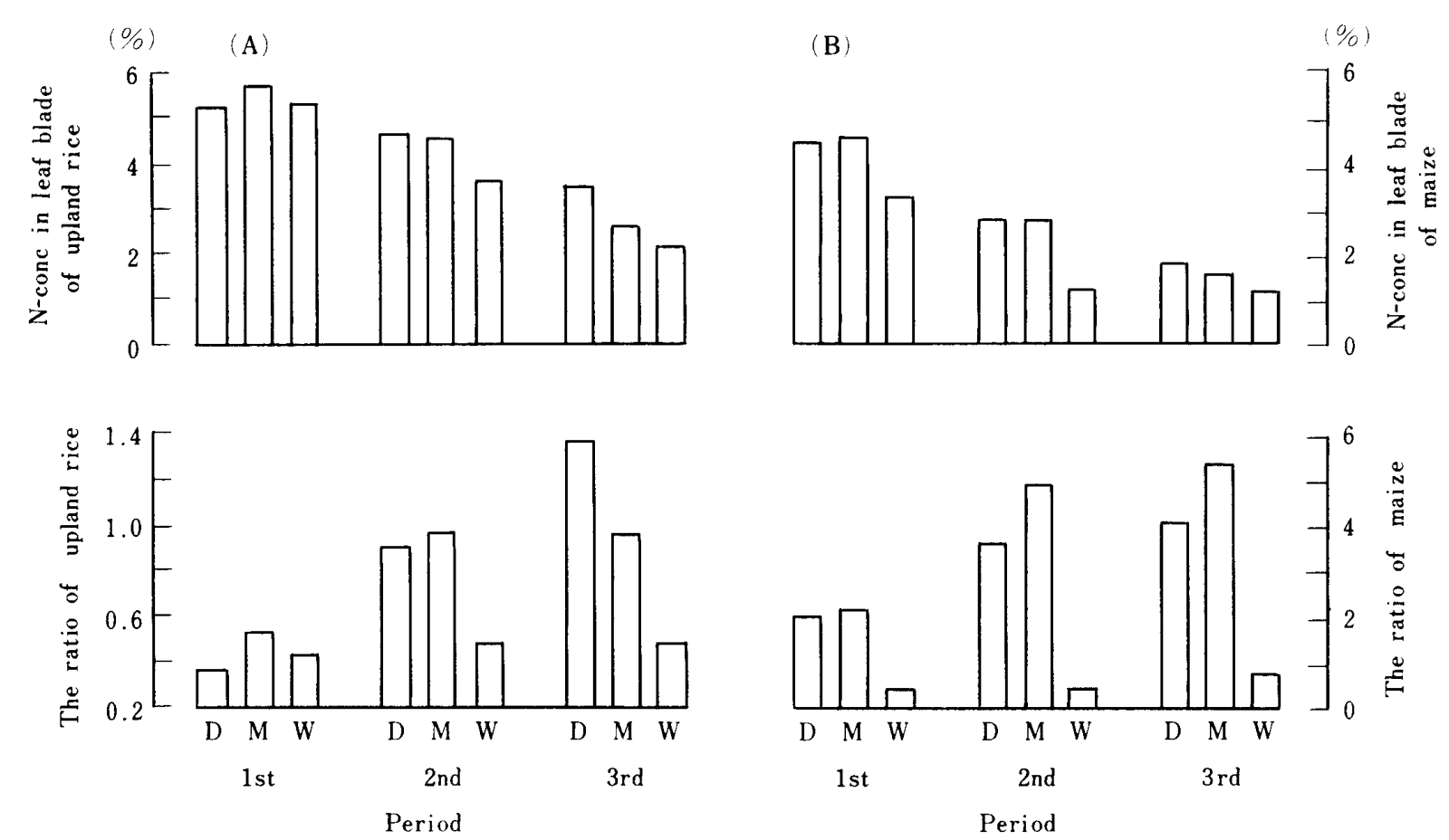

Fig. 6. Differences in nitrogen $(\mathrm{N})$ concentration in leaf blades (above), and in the ratio of $\mathrm{N}$ content in the whole leaf blades to the number of roots of a plant (below) for upland rice (A) and maize (B) grown under different soil moisture conditions.

Note 1) The ratio was obtained by dividing the $\mathrm{N}$ content of the whole leaf blades by the total number of roots of a plant.

2) Legends are the same with those in Fig. 5.

the first period, but they did not agree well in maize. This indicates that waterlogged and drought conditions affected LAR of upland rice through $\mathrm{N}$ concentration in leaf blades during the younger stage, while LAR of maize was not influenced so much by the $\mathrm{N}$ concentration under those soil moisture conditions.

Furthermore, the difference of NAR between the $\mathrm{D}$ - and the $\mathrm{W}$-plot was found to be closely related to that of $\mathrm{N}$ concentration in leaf blades in upland rice as well as maize (Fig. 6). Therefore, this indicates that different soil moisture conditions affected NAR and thus RGR of the two species largely through $\mathrm{N}$ level in leaf blades.

$\mathrm{N}$ level in leaf blades is in turn closely related to the root activity through $\mathrm{N}$ absorption and cytokinin production ${ }^{16)}$. In general, nutrient uptake by roots is reduced under drought conditions because of reduced soil water and the inhibition of root activity ${ }^{14)}$ and under waterlogged conditions due to soil nitrogen status and impaired root activity ${ }^{8}$. Similarly, cytokinin production by the roots and its transportation to shoots is inhibited by water stress $^{10)}$ and waterlogged conditions together with the acceleration of senescence of leaves ${ }^{15)}$.

Assuming that the $\mathrm{N}$ absorption activity of the roots was expressed by means of the ratios of $\mathrm{N}$ content in the whole leaf blades to the number of roots in each plant (Fig. 6), the relationship between the root activity and NAR was examined. Comparing the relative position of each ratio between the $\mathrm{D}$ - and the $\mathrm{W}$-plots at a given period with the relative position of NAR and RGR between the twoplots during corresponding period (Fig. 5), good correspondences were found between them during the first and the second periods. Besides, during the second period, when maize showed exceptionally high NAR in the M - plot (Fig. 5) as compared with its $\mathrm{N}$ concentration in the leaf blade (Fig. 6), the ratio in the $\mathrm{M}$-plot was also higher than the other two plots.

These facts indicate that NAR and RGR were under the great influence of $\mathrm{N}$ level in leaf blades; and the root activity of each species exhibited under respective soil moisture conditions influenced largely the $\mathrm{N}$ level in the leaf blade, and consequently NAR and RGR. Kujira ${ }^{9)}$ also found an intimate relation- 
ship between the root activity and RGR of shoot in rice plant. He expressed the root activity by $\alpha$-naphthylamine oxidizing activity which is closely connected to the respiration and thus nutrient absorption of the roots.

However, distinctively vigorous growth of each species exhibited during the first period (in the $\mathrm{W}$-plot for upland rice and in the $\mathrm{D}$ -plot for maize) in our present experiment (Figs. 1, 4 and 5) can not be explained only by the root activity. Here, it is noteworthy that in each case the root growth in terms of RGR was greater than those observed in the other two plots (Fig. 4). In relation to this respect, Humphries and Thorne ${ }^{5)}$, and Murata et al. ${ }^{12)}$ reported that root growth directly affected photosynthesis for the root functioned as a sink of photosynthate.

Therefore, these results indicate that the activity as well as the growth of roots played significant roles in how the different soil moisture conditions affected the whole plant growth. In other words, the differences in the growth responses of these two species largely depended upon those in the responses of roots to different soil moisture conditions.

In the exceptional case, which was mentioned earlier, when RGR of upland rice in the $\mathrm{W}$-plot was lower than in the $\mathrm{D}$-plot (Fig. 4), the root activity (Fig. 6) and growth (Figs. 1 and 4) were also much lower in the W-plot than those observed in the other two plots. This may be attributed to an inhibitive effect of soil reduction caused by a rapid rise of temperature during this period. Therefore, in order to study the waterlogging and drought tolerances of the crops, the growth and activity of their roots under different soil moisture conditions are to be investigated fully.

This work was supported by the Grant -in-Aid for Scientific Research from the Ministry of Education, Science and Culture of Japan (59360002).

\section{References}

1. Arikado, H. 1975. Ventilating system and excess -moisture tolerance in crops. Dept. Crop Science, Fac., Agr., Mie Univ., Tsu. Japan. 50-95*.

2. Hsiao, T.C. 1973. Plant responses to water stress. Ann. Rev. Plant Physiol. 24 : 519-570.

3. _ and E. Acevedo. 1974. Plant responses to water deficits, water-use efficiency and drought resistance. Agric. Meteorol. 14: 59-84.

4. Itoh, R. and A. Kumura 1986. Acclimation of soybean plants to water deficit. I. Effects of prolonged water deficit on the production and partition of dry matter. Japan. Jour. Crop Sci. 55 : 367 $-373$.

5. Humphries, E.C. and G.N. Thorne. 1964. The effect of root formation on photosynthesis of detached leaves. Ann. Bot. NS. 28 : 391-400.

6. Jackson, M. and M. Drew. 1984. Effects of flooding on growth and metabolism of herbaceous plants In Fooding and Plant Growth (Ed) T.T. Kozlowski, Academic Press, Orlando. 47-128.

7. Kono, Y., A. Yamauchi, N. Kawamura, J. Tatsumi, T. Nonoyama and N. Inagaki. 1987. Interspecific differences of the capacities of waterlogging and drought tolerances among summer cereals. Japan. Jour. Crop Sci. 56 : 115-129.

8. Kozlowski, T.T. and S.G. Pallardy. 1984. Effect of flooding on water, carbohydrate, and mineral relation. In Flooding and Plant Growth (Ed) T.T. Kozlowski, Academic Press, Orlando. 165-193.

9. Kujira, Y. 1984. The relationship between the root growth analysis and the growth analysis in the paddy rice at the vegetative stage. Japan. Jour. Crop Sci. $53: 41-46^{*}$.

10. Milborrow, B.V. 1981. Abscisic acid and other hormones. In The Physiology and Biochemistry of Drought Resistance in Plants (Eds) L.G. Paleg and D. Aspinall, Academic Press, Sydney. 347 -388 .

11. Miller, D.E. 1986. Root systems in relation to stress tolerance. HortScience. $21: 963-970$.

12. Murata, Y., J. Iyama and T. Honda. 1965. Studies on the photosynthesis of rice plants. XIII. On the interrelationships between photosynthetic activity of the leaf and physiological activity of the root. Proc. Crop Sci. Japan. 34 : 148-153.

13. Passioura, J.B. 1981. Water collection by roots. In The Physiology and Biochemistry of Drought Resistance in Plants (Eds) L.G. Paleg and D. Aspinall, Academic Press, Sydney. 39-53.

14. Pitman, M.G. 1981. Ion uptake. In The Physiology and Biochemistry of Drought Resistance in Plants (Eds) L.G. Paleg and D. Aspinall, Academic Press, Sydney. 71 -96.

15. Reid, D.M. and K.J. Bradford 1984. Effects of flooding on hormone relations. In Flooding and Plant Growth (Ed) T.T. Kozlowski, Academic Press, Orlando. 195-219.

16. Skene, K.G.M. 1975. Cytokinin production by roots as a factor in the control of plant growth. In Development and Function of Roots (Eds) J.G. Torrey and D.T. Clarkson, Academic Press, London. $365-396$. 
17. Takeda, T.,S. Hakoyama, W. Agata and S. Furuya. 1980. Studies on weed vegetation in non -cultivated paddy field. III. Effects of different soil moisture levels on growth during early stage of some summer grasses. Japan. Jour. Crop Sci. 49 : 432-438*.

18. Tazaki, T., H. Yonemitsu, H.Miyake and T. Ushijima. 1982. Limit of growth adaptation of some agricultural crops to drying atomosphere and soil. In F-1 Rep. of Spec. Res. Project of the Ministry of Education, Science, and Culture of Japan (5712006-999). 1-22**.

19. Wenkert, W., N.R. Fausey and H.D. Watters. 1981. Flooding responses in Zea mays L. Plant Soil. $62: 351-366$.

* In Japanese with English summary.

** Translated from Japanese by the present authors. 